MARIUSZ LACH

\title{
AMATORSKIE REALIZACJE TEATRALNE DRAMATÓW KAROLA WOJTYŁY
}

Twórczość dramaturgiczna Karola Wojtyły dla teatru została odkryta po jego wyborze na Stolicę Piotrową. Wcześniej nie skupiano się szczególnie na tym aspekcie jego pisarstwa. Dopiero, gdy nagle świat się o nim dowiedział, różni badacze (zarówno literaturoznawcy, jak i teatrolodzy) dostrzegli bogactwo jego literackiego dorobku. I jak rozważania czy poezje w miarę prosty sposób udostępniono odbiorcom, zwłaszcza czytelnikom, tak także zaczęto przygotowywać realizacje sceniczne nieznanych dotąd dramatów Wojtyły. Zarówno te wcześniejsze, należące do okresu młodzieńczej twórczości: Hiob (1940), Jeremiasz (1940) - będące biblijnymi trawestacjami sensu życia w dobie zmagań wojennych, jak i późniejsze: Brat naszego Boga (1949/50), Przed sklepem jubilera (1960) czy Promieniowanie ojcostwa (1964), stanowiące rozważania na temat wartości ludzkiej egzystencji, stały się nagle źródłem tekstów gotowych do realizacji scenicznych.

\section{RECEPCJA TWÓRCZOŚCI DRAMATURGICZNEJ NA SCENACH ZAWODOWYCH}

Żeby móc rzeczywiście dostrzec wartość działań teatrów amatorskich w upowszechnianiu teatralnych tekstów Wojtyły, należy najpierw dostrzec to, co w tej materii uczyniły środowiska zawodowe. Na tle tej zarysowanej, z oczywistych

Ks. dr MARIUSZ LACH SDB - adiunkt Katedry Dramatu i Teatru w Instytucie Literaturoznawstwa KUL; kierownik Teatru ITP; adres do korespondencji: Katolicki Uniwersytet Lubelski Jana Pawła II, Al. Racławickie 14, 20-950 Lublin; e-mail: mariusz.lach@kul.lublin.pl. ORCID: http://orcid.org/ 0000-0001-7011-7480. 
względów w sposób skrótowy, panoramie można zauważyć wartości i osiągnięcia nieprofesjonalnych (chociaż tylko z nazwy) grup scenicznych.

Wybór Karola Wojtyły na papieża stał się naturalnym momentem intensyfikacji różnego rodzaju spektakli opartych na jego twórczości. Dokumentację tego zjawiska można znaleźć wśród materiałów zajmujących się badaniem recepcji teatralnej w Polsce na portalu www.e-teatr.pl ${ }^{1}$. Są tam zarchiwizowane i opisane w fachowy sposób ważniejsze przedstawienia oparte zarówno na dramatach, jak i innych tekstach zebranych Karola Wojtyły - Jana Pawła II. Opisano tam zarówno realizacje Teatru TV, Teatru Polskiego Radia, jak i scen zawodowych z całego kraju. Warto w tym miejscu zrobić małe podsumowanie tych przedsięwzięć, skupiając się na spektaklach zagranych na deskach teatrów.

Hiob był przedstawiony tylko 5 razy: pierwszy raz w Teatrze Ludowym w Krakowie-Nowej Hucie w 1983 roku. Ostatnia znana realizacja miała miejsce w 2009 roku w Teatrze Dramatycznym im. Aleksandra Węgierki w Białymstoku. Jeszcze mniej adaptacji scenicznych doczekał się Jeremiasz. Był wystawiany tylko w trzech miejscach (Bielsko-Biała w 1981 roku, w Bydgoszczy w 1983 roku oraz w Płocku w 1991). Co ciekawe, wszystkie te spektakle reżyserował Marek Mokrowiecki. Brat naszego Boga był przenoszony na scenę trzynaście razy. Pierwsza realizacja miała miejsce w Krakowie w Teatrze im. Juliusza Słowackiego w 1980 roku, zaś ostatnia w Teatrze im. Juliusza Osterwy w Gorzowie Wielkopolskim w roku 2017. Ostatni $\mathrm{z}$ dramatów to Przed sklepem jubilera. W tym przypadku można mówić o największej popularności tekstu dramatycznego Wojtyły, gdyż przenoszono go na scenę aż piętnaście razy. Pierwsza teatralna odsłona tego tekstu miała miejsce w Teatrze Polskim ZASP w Londynie w 1979 roku², czyli bezpośrednio po wyborze Wojtyły na Stolicę Piotrową. Ostatnia została przygotowana przez Teatr Mały w Tychach w 2013 roku. Warto tutaj nadmienić, że aż dziewięć z tych piętnastu przedstawień przygotował, w różnych miejscach i w różnej obsadzie, Andrzej Maria Marczewski, jeden z częściej skupiających się na twórczości Wojtyły reżyserów.

Dużą rolę w promowaniu twórczości dramaturgicznej Wojtyły miały teatry radia i telewizji. To właśnie tam można było zobaczyć bądź usłyszeć świetnie zrealizowane przedstawienia w doborowym składzie. Należy jednak zwrócić uwagę, że liczba tych realizacji jest różna. Polskie Radio przygotowało siedemnaście spektakli opartych na różnych, nie tylko dramaturgicznych, tekstach Wojtyły. Brat naszego Boga był

${ }^{1}$ www.e-teatr.pl/pl/realizacje/1179, autor.html. Dostęp 10.03.2020. Na stronie tej znajduje się spis spektakli zrealizowanych na podstawie tekstów Karola Wojtyły wraz z podstawowymi informacjami na ich temat.

${ }^{2}$ Przed SklePem JUbILERA, premiera: 25 IV 1978, reżyseria - Leopold Kielanowski, scenografia - Kinga Kozerska, muzyka - Andrzej Panufnik. 
realizowany trzy razy w latach 1983, 1992 oraz 2007, Przed sklepem jubilera jeden raz w 1982 roku, zaś Promieniowanie ojcostwa również jeden raz w 2003 roku. Teatr Telewizji przygotował tylko dwa spektakle oparte na omawianych dramatach. Były to Promieniowanie ojcostwa (1987) oraz najnowszy, przygotowany z okazji roku Adama Chmielowskiego Brat naszego Boga (2017). Promieniowanie ojcostwa, jako ostatni z omawianych dramatów nie doczekał się osobnej, indywidualnej realizacji zawodowych środowisk teatralnych.

Wymienione wyżej teksty to dramaty, które były w całości przenoszone na sceny. Należy jednak zauważyć, że w Polsce przy różnych tzw. papieskich okazjach przygotowywano spektakle będące często kompilacjami jego różnych, często poetyckich wypowiedzi. Interesującymi i zarazem godnymi zauważenia są różnorodne radiowe realizacje tekstów Karola Wojtyły, które napisał już jako Jan Paweł II. Były one bardzo często przygotowane przez doborowych aktorów scen polskich, w świetnych opracowaniach muzycznych. Warto tu wymienić choćby List ojca świętego Jana Pawta II do ludzi w podeszłym wieku zaprezentowany przez Andrzeja Seweryna $\mathrm{z}$ towarzyszeniem zespołu muzycznego Nahorny-Sextet ${ }^{3}$ czy też Narodziny świętych dla nieba z 2006 roku$^{4}$.

Jeszcze inną formą promującą i skupiającą się na twórczości literackiej Wojtyły są filmowe adaptacje jego dramatów. W roku 1988 Michael Anderson z doborową, międzynarodową obsadą (Ben Cross, Olivia Hussey i Daniel Olbrychski) zrealizował włosko-kanadyjski film The Jeweller's Shop ${ }^{5}$, oparty na dramacie Przed sklepem jubilera. W 1997 roku Krzysztof Zanussi przeniósł na ekran Brata naszego Boga realizując film Our God’s Brother ${ }^{6}$. Była to koprodukcja polsko-włosko-nie-

${ }^{3}$ List ojCa ŚWiętego Jana PawŁa II do LudZi w PODESZlym wiekU, słuchowisko zrealizowane przez Polskie Radio odbyło się 6 IV 2013 roku, w reżyserii Wojciecha Przybylskiego, wybór tekstów - Tadeusz Pieronek.

${ }^{4}$ NARODZINY ŚWIĘTYCH DLA NIEBA, premiera: 2 IV 2006, adaptacja i reżyseria - Zdzisław Dąbrowski, wystąpili m.in. Krzysztof Gosztyła, Andrzej Ferenc, Krzysztof Kolberger, Grzegorz Damięcki.

${ }^{5}$ THE JewelleR's SHop. Michael Anderson, znany amerykański reżyser, autor kilku kasowych przebojów, zrealizował w międzynarodowej koprodukcji i obsadzie ekranizację młodzieńczego dramatu Papieża Przed sklepem jubilera. Jest to apoteoza zwykłej ludzkiej miłości, rozdartej między zmysłowością a duchowością. Dla Karola Wojtyły prawdziwą miłością jest odnalezienie siebie w drugim człowieku, a miłość małżeńska opiera się na budowaniu pomostu między przeszłością a przyszłością. Film ukazuje losy ludzi, którzy kochają - choć nie każdy z nich uświadamia sobie, na czym polega dążenie do miłości spełnionej. Por. https://www.filmweb.pl/film/Przed+sklepem+jubilera-1989-7011. Dostęp 20.04.2020.

${ }^{6}$ Our GoD’s Brother. Adaptacja sztuki Karola Wojtyły. W teatrze trwają przygotowania do przedstawienia, wykonawca głównej roli opowiada o swym bohaterze, Adamie Chmielowskim, malarzu i duchownym. Stopniowo akcja przenosi się z garderoby teatralnej na scenę, potem na ulice i do wnętrz XIX-wiecznego Krakowa. Reżyseria - Krzysztof Zanussi, premiera 8 VI 1997. Por. www.filmweb.pl/ film/Brat+naszego+Boga-1997-570. Dostęp 20.04.2020. 
miecka, zaś główne role zagrali: Scott Wilson, Christoph Walz, Wojciech Pszoniak i Grażyna Szapołowska?

\section{ZMNIEJSZAJĄCA SIĘ LICZBA PRZEDSTAWIEŃ KAROLA WOJTYŁY NA SCENACH ZAWODOWYCH}

Opisane wyżej realizacje będące bądź bezpośrednim przełożeniem dramatów na deski teatralne, czy też adaptacjami twórczości Karola Wojtyły w pewnym momencie wyraźnie zmniejszyły częstotliwość pojawiania się na zawodowych scenach. Ich intensyfikacja, kolejne wznowienia były wcześniej ściśle powiązane z wydarzeniami skupionymi wokół osoby Jana Pawła II. Kolejne rocznice wyboru na Stolicę Piotrową, pielgrzymki do ojczyzny, Światowe Dni Młodzieży, wreszcie śmierć Papieża pobudzały różne osoby i instytucje do tego, aby ponownie przyjrzeć się osobie wielkiego Polaka, często skupiając się na jego literackiej spuściźnie. Jednak w miarę lat artystyczne środowiska zawodowe coraz rzadziej sięgały do jego twórczości pisarskiej.

Można się dopatrywać różnych przyczyn tego osłabienia zainteresowania pisarstwem Wojtyły. Zmieniające się nastroje społeczne, mniejsza możliwość komercjalizacji znanych przecież dramatów, czy słabnące zainteresowanie twórców sprawiły, że na zawodowych scenach coraz rzadziej pojawiały się nowe realizacje papieskich dramatów.

Przytoczone wyżej projekty teatralno-filmowe zostały zauważone i docenione przez krytykę i publiczność. Można znaleźć ich różne recenzje, opracowania czy opisy, zarówno te badające wieloaspektowość tych dzieł przez zawodowych krytyków, jak i pozytywne skutki, które wywołały wśród odbiorców, widzów. W czasach, kiedy tempem życia, także artystycznego, zaczyna rządzić komercja i niezrozumiała forma często ocierająca się o banał, podejmowanie tematów religijnych opartych na twórczości kapłana - artysty - dramaturga nie jest rzeczą łatwą. I wydawałoby się, że właśnie dramaturgia opisująca językiem poetyckim egzystencjalne aspekty z życia nie znalazła odbiorców. Nic bardziej błędnego. Gdy z jednej strony promuje się coraz wyraźniej treści atakujące postawy i idee, którymi się kierował Jan Paweł II (choćby przytaczając spektakl Klątwa w realizacji Teatru Powszechnego z Warszawy), z drugiej należy dostrzec ciągle pojawiające się nowe inicjatywy teatralne, inspirowane myślą, życiem i twórczością Wojtyły.

\footnotetext{
${ }^{7} \mathrm{Na}$ temat recepcji twórczości Wojtyły zobacz A. KRUSzYŃsKa, Karol Wojtyła: aktor, poeta, dramaturg, www.e-teatr.pl/pl/artykuly/265550,druk.html. Dostęp 15.04.2020.
} 
Obok licznej grupy wydarzeń artystycznych, mających oparcie w profesjonalistach i wielkim zapleczu technicznym, należy dostrzec inny nurt, również skupiający się na twórczości dramaturgicznej Karola Wojtyły. Sceny amatorskie, teatry młodzieżowe, szkolne, studenckie, grupy niesformalizowane, duszpasterstwa i wspólnoty religijne, pojedyncze osoby angażujące się w promowanie twórczości Papieża, są drobną egzemplifikacją większego ruchu. Jest wiele środowisk, które bardzo intensywnie, choć z różną jakością tworzą formy sceniczne oparte na twórczości Wojtyły. W przeważającej mierze są to grupy parafialne, teatry seminaryjne czy różnego rodzaju inicjatywy, które działały jednorazowo, projektowo, na miarę konkretnych potrzeb. Niestety, są one trudne do opisania, gdyż w większości nie zachowały się żadne dokładniejsze opisy ich teatralnych prezentacji. W poniższych refleksjach skupiono się jednak na tych zespołach czy spektaklach, które działają systematycznie, mają swój bardzo często bogaty dorobek sceniczny oraz nieustannie podnoszą swoje aktorsko-teatralne kwalifikacje.

\section{NAJWAŻNIEJSZE DRAMATY KAROLA WOJTYŁY W REALIZACJI SCEN AMATORSKICH}

Od początku pontyfikatu Jana Pawła II jego dramaty odkryte dla czytelników i masowo publikowane stały się materiałem chętnie wykorzystywanym przez teatry amatorskie. Różnego rodzaju rocznice związane z życiem Ojca Świętego stawały się inspiracją do ponownego sięgania do jego nauczania i promowania myśli papieskiej wśród wiernych. Przy tych okazjach poszczególne diecezje, grupy, wspólnoty czy inne stowarzyszenia mające Jana Pawła II za swojego patrona przygotowywały się duchowo do obchodów różnych uroczystości. „Wiązało się to z ponownymi realizacjami dramatów Wojtyły, tworzeniem wieczornic opartych na poezji papieża, czy też próbami ukazywania nauczania papieskiego w postaci spotkań z artystami. Miały one bardzo często miejsce w kościołach katedralnych, ale także mniejszych parafiach. Przygotowywane przez seminarzystów stawały się refleksją nad treściami zawartymi w utworach literackich albo samego papieża, albo wielkich polskich poetów" (Lach, Kilka szkiców 37).

Wśród tych wydarzeń warto zwrócić uwagę na te dramaty, które były najczęściej realizowane przez amatorów. Dramaty młodzieńcze - Jeremiasz i Hiob, prawdopodobnie z racji swojej rozbudowanej formy, jak i biblijno-poetyckiego języka były rzadziej przenoszone na scenę. $Z$ tych dwóch jedynie Hiob doczekał się realizacji 
w 2012 roku przez Teatr Karola ${ }^{8}$. Był to pierwszy pełny tekst dramatyczny przygotowany i opracowany przez ten zespół. Dzięki wpisaniu starotestamentalnej opowieści w kontekst życia duchowego, młodzi aktorzy próbowali wniknąć w odwieczny problem walki między dobrem i złem, ukazując starcie łagodności i gniewu oraz pokory i pychy. Młodzież starała się ukazać widzom Bożą logikę w wydarzeniach pozornie okrutnych i niesprawiedliwych. Skupiła się ona na sytuacji człowieka poniżonego, pytając o źródła jego wytrwałości w cierpieniu. Aktorzy chcieli przy tej okazji szukać w osobie umęczonego i poniżonego Hioba kogoś współczesnego, bliskiego, kogoś, kto może pokazać człowiekowi początku XXI wieku, co tak naprawdę jest w życiu ważne. Spektakl był inscenizacją dramatu, odwołującą się jednak formalnie do konwencji wypracowanej przez Teatr Rapsodyczny. W przedstawieniu można było dostrzec bardzo wyraźnie ślady antyczne, mocno sugerowane w samym utworze. Warstwa językowa, będąca trudną w odbiorze dla współczesnego widza i wymagająca skupienia i zasłuchania, nie przeraziła twórców. Scenariusz na podstawie dramatu napisał Maciej Omylak, reżyserii podjęła się Agata Wieczorek, zaś za warstwę muzyczną odpowiadał Maciej Smółka.

Brat naszego Boga był dla aktorów amatorów dramatem łatwiejszym do realizacji. Jest tam więcej postaci, tematyka bliższa współczesności, a i problematyka łatwiejsza w przekazie scenicznym. Przeniesienia tego dramatu na scenę podjęła się poznańska grupa studencka AGAPE $^{9}$, działająca przy Duszpasterstwie Akademickim PLUS. Nazwą grupy jest akronim od słów Akademicka Grupa Amatorskich Pasjonatów Aktorstwa. Zamysłem zespołu było jednak, by jego nazwa była czymś więcej, niż tylko zabawą lingwistyczną. Miała ona określać przyświecające grupie idee ${ }^{10}$. Brat naszego Boga - jako tekst dramatyczny idealnie wpisuje się w założenia wspólnoty. Napisania scenariusza i reżyserii podjął się ówczesny lider grupy Michał Wieliczuk, zaś sam spektakl jest wiernym przełożeniem treści sztuki na język teatralny, którym operują poznańscy studenci. Akcja ich przedstawienia rozgrywa się w środku zimy. Widzowie spotykają Adama Chmielowskiego odwiedzającego parokrotnie miejskie ogrzewalnie, będące schronieniem dla bezdomnych. Spektakl pokazuje, jak zmienia się główny bohater poprzez swoje czyny, decyzje i przemyślenia. Środki, jakimi operuje teatr i bardziej amatorskie doświadczenia teatralne, nie pozbawiły tekstu Wojtyły siły wyrazu. Liczne jego kolejne przedstawienia oraz publiczność tłumnie

\footnotetext{
${ }^{8}$ Teatr Karola - to grupa młodzieżowa działająca w Gliwicach w latach 2008-2019, pod kierownictwem Macieja Omylaka. W jej skład wchodziła młodzież gliwickich szkół średnich. centrumedukacyjnejp2.p1/teatr-karola. Dostęp 20.04.2020.

${ }^{9}$ AGAPE - grupa teatralna działająca przy klasztorze oo. Franciszkanów przy placu Bernardyńskim w Poznaniu. daplus.franciszkanie.net/grupy/grupa-teatralna. Dostęp 20.04.2020.

${ }^{10}$ Zespół wybierając tę nazwę pragnął przez swoje zamiłowanie do teatru właśnie jako wspólnoty trwać w radości i dzielić się nią, operować na płaszczyźnie spotkania z drugim człowiekiem.
} 
je odwiedzająca potwierdzały potrzebę właśnie takiego, czystego i prostego przełożenia dramatu na scenę.

Ten sam tekst, ale przygotowany i zagrany tylko jeden raz, zaprezentował Teatr ITP $^{11}$ z Katolickiego Uniwersytetu Lubelskiego Jana Pawła II. Miało to miejsce podczas spotkania naukowo-kulturalnego „Dwugłos o Bogu i poezji” z udziałem prof. Zofii Zarębianki i prof. Mirosławy Ołdakowskiej-Kuflowej ${ }^{12}$. Teatr akademicki zaprezentował wtedy czytanie dramatu Brat naszego Boga, pod kierownictwem aktora Teatru Provisorium - Jacka Brzezińskiego. Studenci, w stonowanej i prostej scenografii, czytając tekst Wojtyły aranżowali poszczególne sceny dramatu. Nie mogąc $\mathrm{w}$ pełni oddać całego bogactwa treści, reżyser skupił uwagę na ukazaniu wewnętrznej walki głównego bohatera z jego alter ego. Trudne decyzje w poszukiwaniu większego dobra i w konsekwencji rezygnacja z dotychczasowej „kariery”, a także pełne poświęcenie dla ludzi odrzuconych na margines społeczeństwa, były obrazami, które po spektaklu na długo zostawały w pamięci.

Obie realizacje są tylko przykładami na to, że dramat Brat naszego Boga ciągle jest tekstem aktualnym i potrzebnym. Jednak pewnie z racji dosyć dużej obsady aktorskiej i rozbudowanych przestrzeni scenicznych nie był on tym, który teatry amatorskie najchętniej wykorzystywały.

Czwarty z dramatów Karola Wojtyły, najczęściej realizowany także przez zespoły profesjonalne, to Przed sklepem jubilera. Stosunkowo mała obsada, ale przede wszystkim ciągle ważna i aktualna problematyka przyczyniły się do tego, że również na scenach nieprofesjonalnych był on często wystawiany.

Wśród polskich, uznanych już teatrów amatorskich realizacji tego dramatu podejmowało się sporo różnych grup. Za najbardziej popularną i zbierającą wiele bardzo dobrych recenzji należy uznać grupę Logos ${ }^{13}$. Teatr ten wyrósł z działań przyparafialnych, zrzeszających młodzież w łódzkiej dzielnicy Bałuty. Początkowo był to zespół zupełnie amatorski, funkcjonujący pod nazwą Parafialny Teatr Słowa, który w miarę lat przekształcił się w najbardziej uznany w Polsce amatorski teatr religijny (niemniej działający bardzo profesjonalnie). Przed sklepem jubilera po raz pierwszy zrealizowany został na początku artystycznej drogi łódzkiej grupy w 1988 roku. Był on wyreżyserowany przez kierownika teatru ks. Waldemara Sondkę, scenografię

${ }^{11}$ TeATR ITP - grupa teatralna działająca w Katolickim Uniwersytecie Lubelskim Jana Pawła II, www.teatritp.kul.lublin.pl. Dostęp 20.04.2020.

${ }^{12}$ „22.10 Wydarzenie naukowo-kulturalne 'Dwugłos o Bogu i poezji'”. www.kul.pl/art 76904. html. Dostęp 15.03.2020.

${ }^{13}$ Teatr Logos działa przy Kościele Rektoralnym Środowisk Twórczych w Łodzi. Rozpoczął swoją działalność 2 listopada 1987 r. z inicjatywy ks. Waldemara Sondki. Do tej pory przygotował 55 spektakli premierowych i zagrał prawie 2200 przedstawień. 2 listopada $2019 \mathrm{r}$. Teatr obchodził swoje trzydzieste drugie urodziny. www.logos.art.pl. Dostęp 15.03.2020. 
przygotowała Urszula Klechta, zaś oprawą muzyczną zajął się Janusz Kwiatosiński. W spektaklu brało udział ponad dwudziestu młodych aktorów, a on sam został zaprezentowany dwadzieścia cztery razy. Ponownie, po dwudziestu czterech latach, w 2012 roku Logos przygotował kolejną realizację tegoż tekstu, wystawiając ją tym razem pod tytułem Medytacja o sakramencie matżeństwa przechodzaca chwilami $w$ dramat. Przedstawienie powstało pod opieką profesjonalistów łódzkich scen reżyserią zajął się Marek Kasprzyk, za scenografię odpowiadał Ryszard Warcholiński, zaś oprawy muzycznej podjął się Marek Targowski. Zrealizowane w bardziej kameralnej i wyciszonej formie, gdzie aktorom zawodowym partnerowali amatorzy (tj. bez profesjonalnego wykształcenia scenicznego), spotkało się z bardzo dobrym odbiorem lokalnych krytyków teatralnych. Było ono zagrane dwadzieścia razy.

Również wspominany wcześniej Teatr Karola w swym repertuarze posiadał sceniczne opracowanie tego tekstu. W 2015 roku przygotowali oni Medytację nad sakramentem matżeństwa, będącą wiernym przełożeniem na scenę omawianego dramatu. Jak w większości ich spektakli, reżyserią zajęli się Maciej Omylak i Agata Wieczorek, zaś za muzykę odpowiadała Krystyna Szymura. W tym przedstawieniu aktorzy postanowili przesunąć punkt ciężkości z pracowni jubilera na rozważanie o istocie domu i rodziny w kształtowaniu osobowości młodego człowieka. Skupiając się na historii miłości Moniki i Krzysztofa, a także wskazując na jej źródła, którymi są losy ich rodziców, przedstawienie to stało się refleksją nad istotą małżeństwa. Była to pewnego rodzaju medytacja nad losem człowieka postawionego wobec trudnych wyborów. Gliwiccy twórcy w swym przedstawieniu skupili się na obrazie pięknej miłości przeplatającej się z historią ludzkiej słabości i grzechu.

Podczas obchodów Roku Świętego Jana Pawła II na Katolickim Uniwersytecie Lubelskim, noszącym imię wielkiego Polaka, została zorganizowana sesja pod nazwą „Karol Wojtyła, Jan Paweł II: filozof, poeta, papież, święty”, na potrzeby której Teatr ITP przygotował własną inscenizację przytaczanego dramatu pod tytułem Historie jubilera. W zakładzie fotograficznym wnuczki dawnego jubilera spotkały się różne osoby, aby zrobić sobie pamiątkowe zdjęcia. Wspomnienie miejsca i osoby starego sprzedawcy obrączek wywołało refleksję na temat indywidualnych dróg poznawania miłości. Wnuczka przypominała słowa swego dziadka, zaś tajemnicza postać świadka tamtych wydarzeń sprawiła, że tematy dotyczące miłości były aktualne dla wszystkich odwiedzających atelier. Obok podstawowych fragmentów dramatu Wojtyły pojawiły się utwory muzyczne czerpiące swe teksty z innych, poetyckich wyznań dramaturga. Przedstawienie przygotowane w reżyserii ks. Mariusza Lacha, choć zaprezentowane zostało tylko jeden raz, zgromadziło wielką widownię i zebrało pozytywne recenzje.

Wymienione i opisane wyżej spektakle są tylko przykładami wskazującymi na ciągłą żywotność i potrzebę realizacji dramatów Wojtyły. Gdy ostatnimi czasy środo- 
wiska zawodowe coraz rzadziej wracają do omawianej twórczości, grupy amatorskie coraz bardziej profesjonalnie wracają do tekstów Karola Wojtyły.

\section{TEATRY AMATORSKIE HOŁDEM ZŁOŻONYM PAPIEŻOWI - DRAMATURGOWI I AKTOROWI}

Oprócz samych przedstawień, czy to wchodzących w skład repertuaru teatrów czy też przygotowywanych jednorazowo - powinno się dostrzec środowiska teatralne powstałe w celu propagowania właśnie literackiej spuścizny Karola Wojtyły. Pierwszą grupą, której należy się refleksja, jest gliwicki Teatr Karola. W październiku 2008 roku, z okazji rocznicy pontyfikatu Jana Pawła II grupa uczniów z II LO w Gliwicach przygotowała montaż poetycko-muzyczny do tekstów Karola Wojtyły i Jana Twardowskiego pt. Nie lękajcie się. Nazwa, repertuar i forma działań tego zespołu były naturalną konsekwencją tego pierwszego pragnienia. Teatr Karola to przede wszystkim teatr słowa, nawiązujący wyraźnie do Teatru Rapsodycznego Mieczysława Kotlarczyka. Na początku grudnia 2009 roku twórcy teatru: Agata Wieczorek i Maciej Omylak poprosili o błogosławieństwo biskupa diecezjalnego Gerarda Kusza, natomiast 22 grudnia wystawili swój pierwszy spektakl: I zamieszkało wśród nas. Ważnym wydarzeniem, które stało się podwaliną powstałej grupy, była wizyta założycieli teatru w Rzymie. Tam przy grobie Jana Pawła II oddali mu wszystkie swoje teatralne plany. Wtedy to młodzi aktorzy rozpoczęli wspólną drogę grupy przyjaciół skupionych wokół wartości wskazywanych przez Karola Wojtyłę.

Aktorzy i twórcy Teatru Karola początkowo starali się językiem teatralnym opowiadać o życiu ich patrona, zatrzymując się na szczególnych, ważnych dla niego momentach. $\mathrm{Z}$ biegiem lat, w związku z zanikaniem pamięci o ich patronie, zaczęli oni rozszerzać swoje zainteresowania, szukając języka, którym można inspirująco opowiadać zwłaszcza swoim rówieśnikom o świecie wartości reprezentowanym przez Papieża.

Teatr Karola to teatr wartości i jego aktorzy zawsze zdawali sobie sprawę z tego, że zarówno forma, jak i tematyka, są trudne i nie każdy się w tym odnajdzie. Nie rezygnowali jednak ze swych założeń. Dbali przy tym, aby to, o czym mówiło się ze sceny, miało realne przełożenie na ich codzienne życie. Sami zauważali, że przez swoją działalność, zarówno oni, aktorzy teatru, jak i widzowie zbliżają się do osoby i nauczania Papieża. Był to więc teatr, który starał się docierać do ludzkich serc. Niestety w 2019 roku, z powodu przeprowadzenia się twórców teatru do stolicy i braku możliwości ich intensywniejszego zaangażowania w powstałą grupę - teatr tymczasowo zawiesił swoją działalność. 
Teatr Karola przede wszystkim starał się upubliczniać różne teksty Karola Wojtyły. Stąd w ich repertuarze można znaleźć zarówno jego dramaty, listy, fragmenty nauczania. Oprócz tego korzystali z innych gotowych utworów (np. Jana Dobraczyńskiego, ks. Jana Twardowskiego, ks. Mieczysława Malińskiego), adaptując je do swoich potrzeb. Wszystkie jednak ich spektakle są wypełnione ideami, które można znaleźć w nauczaniu Papieża.

Do ich ważniejszych spektakli można zaliczyć realizacje całych dramatów Wojtyły, czyli Hioba i Przed sklepem jubilera, ale także, a może przede wszystkim, różnego rodzaju inscenizacje będące kompilacją zebranych myśli i nauczania Jana Pawła II.

Nie lękajcie się to montaż poetycko-muzyczny przygotowany w 2008 roku, na który składają się fragmenty różnych listów do Karola Wojtyły, stanowiące trzon spektaklu i w symboliczny sposób starające się przekazać i zinterpretować naukę Papieża. Spektakl Wszystko na chwałę Boga (2010) zadedykowany został Janowi Pawłowi II w 32. rocznicę jego wyboru na papieża. Scenariusz powstał na podstawie tekstów Karola Wojtyły i wspomnień wieloletniego papieskiego sekretarza arcybiskupa Mieczysława Mokrzyckiego, zawartych w książce Najbardziej lubit wtorki. Przedstawienie Tobie dam klucze królestwa (2010) zostało oparte na wspomnieniach sekretarzy Jana Pawła II: kardynała Stanisława Dziwisza, arcybiskupa Mieczysława Mokrzyckiego oraz faktografii zawartej w książce Marco Politiego Papa Wojtyła. Pożegnanie. Spektaklem Zostań z nami z roku 2014 gliwiccy aktorzy chcieli dać widzom możliwość pogodnego i pełnego ciepła wspominania Papieża, przypominając jego życie i słowa, czytając jego poezję. Opowiadali o Karolu Wojtyle z perspektywy swojej młodości, szukając w sobie pięknych owoców tego pontyfikatu.

Ciekawostką jest także to, że ostatnimi czasy w teatrze były grane także sztuki z repertuaru, z którego sam korzystał młody Karol Wojtyła, czyli Antygona i Śluby panieńskie. Dzięki temu zabiegowi młodzi adepci sceny ukazywali teatralną drogę, którą przebył jako młody chłopak ich patron, nie tylko jako pisarz, ale także jako aktor. Sięgając w 2017 roku po Antygonę odpowiedzialni za teatr wskazali poniekąd na źródła współpracy Kotlarczyka i Wojtyły. W swej twórczości wrócili do inscenizacji wadowickich, wśród których była także tragedia Sofoklesa. Rok później pokazali Śluby panieńskie Fredry, w których za czasów gimnazjalnych młody Karol Wojtyła wcielał się w postać Gustawa. Tym samym aktorzy gliwickiej grupy po raz kolejny zanurzyli się w przestrzeni rozważań i dylematów młodych ludzi stojących przed podjęciem decyzji o małżeństwie.

Inną grupą z grona amatorskich teatrów chrześcijańskich jest powstały w 2000 roku teatr Droga z Poznania. Tworzy go grupa ludzi, którzy pragną poprzez tworzone spektakle opowiadać o Bogu. Ich twórcy zauważają, że we współczesnym świecie sztuka niesie często przesłanie nihilistyczne, pełne zwątpienia i ciemności. I dlatego chcą przez swoje realizacje teatralne ukazywać radość Ewangelii i promować 
chrześcijańską kulturę. Za patrona swojej teatralnej przygody objęli świętego Jana Pawła II. Jest on im bliski m.in. dlatego, że kochał teatr i był człowiekiem niezwykle wrażliwym na sztukę, poetą i dramatopisarzem. Młodzi twórcy pragną tak jak Papież szczególną troską otoczyć dzieci, młodzież i rodziny. Chcą nieść pomoc rodzicom w chrześcijańskim wychowaniu ich potomstwa, a także przeciwstawiać się niszczącej społeczeństwo i rodziny „kulturze” uzależnienia od środków zmieniających świadomość.

W swojej dwudziestoletniej działalności wielokrotnie korzystali z tekstów Jana Pawła II. I chociaż to nie one były dominującymi treściami w ich repertuarze, to sami często wracali do źródeł i przy różnych okazjach tworzyli przedstawienia oparte na spuściźnie literackiej Wojtyły. W 2005 roku przygotowali Tryptyk rzymski w opracowaniu Heleny Sperskiej-Abbe. W tym przedstawieniu zaprosili widzów do wkroczenia w tajemnicę miłości Boga, w tajemnicę stworzenia, odwiecznego przymierza i odkupienia. Rozważali prawdę i dramat zbawienia człowieka. Spektakl swą formą nawiązywał do krakowskiego Teatru Rapsodycznego. Poemat Pieśń o Bogu ukrytym ukazuje życie wewnętrzne Karola Wojtyły w latach jego młodości. Odtwórcy tego dzieła, przyswajając sobie jego treści i zgłębiając je, wciągali widzów w nurt poetyckiej kontemplacji, we współwyznawanie z Autorem olśnienia pięknem Boga i poznania Jego miłości. Dzielenie to miało charakter teatralnego przekazu w formie rapsodycznej. Czworo aktorów „niosło” myśl, poznanie, aby przekazywać je dalej, obdarowywać nimi widzów, słuchaczy. Głównym nośnikiem teatralnego przekazu jest tekst Pieśni o Bogu ukrytym, który wskazuje na Boga przez swoją treść i brzmienie oraz przez postać je wypowiadającą. Spektakl ten był oszczędny w środkach teatralnych. Jego walory artystyczne, jak piękno i kunszt wypowiedzi, śpiew, wyważony gest, ruch na scenie, interakcje między postaciami, wypływały z dojrzałej wiary wykonawców i autentyzmu ich świadectwa.

Przy Instytucie Dialogu Międzykulturowego im. Jana Pawła II w Krakowie w roku 2013 został zainaugurowany amatorski teatr pod nazwą Scena Papieska ${ }^{14}$. Aktorami w tej grupie są zarówno dzieci, studenci, osoby pracujące, emeryci, a nawet osoby niepełnosprawne. Założycielem i głównym reżyserem jest Leszek Pniaczek, aktor pochodzący z Myślenic, który pragnie odkrywać i upamiętniać myśl i twórczość papieża Polaka. Teatr ten jest otwarty dla wszystkich, zaś jego twórcy starają się przez prowadzone zajęcia budować kulturę wewnętrzną oraz uwrażliwiać innych na piękno sztuki. W miarę lat środowisko to przygotowywało coraz mniej spektakli, skupiając się natomiast na prowadzeniu różnego rodzaju warsztatów teatralnych

${ }^{14}$ „Z kulturą o KULTURZE_2.0” - w siedzibie IDMJP2”. Instytut Dialogu Międzykulturowego im. Jana Pawta II, 21 listopada 2019, idmjp2.pl/index.php/p1/projekty/scena-papieska. Dostęp 15.03.2020. 
czy zajęć dla seniorów. Scena Papieska prowadzi obecnie ciekawy cykl spotkań „Rozmowy Sceny Papieskiej”, do których zapraszani są aktorzy, reżyserzy, ludzie nauki i sztuki, dla których temat sacrum oraz spuścizna literacka Karola Wojtyły stanowi ważne naukowe i duchowe dziedzictwo oraz artystyczne źródło inspiracji. Od pewnego czasu w tym środowisku realizowany jest również projekt zatytułowany Emanacja Rapsodyków, w którym jego twórcy pochylają się nad historią niepowtarzalnego teatru Mieczysława Kotlarczyka.

\section{TEATR NIE DO KOŃCA AMATORSKI}

Na mapie amatorskich środowisk teatrów religijnych jest jeszcze jeden teatr -Hagiograf. Jest on teatrem słowa, kontynuatorem idei Teatru Rapsodycznego Mieczysława Kotlarczyka. Został założony przez Izabelę Drobotowicz-Orkisz w Krakowie. Od marca 2001 roku działa pod obecną nazwą i współpracuje z wieloma krakowskimi aktorami, muzykami i naukowcami. Pierwszy spektakl pod szyldem tego teatru odbył się 10 marca 2001 roku w kościele Świętego Krzyża w Krakowie. Sztandarowy monodram swojej sceny artystka dedykowała Janowi Pawłowi II. Wszystkie projekty teatru mają za zadanie, ukazując dobro i piękno, zbliżać człowieka do Boga. Odwoływanie się do logosu, dbałość o kulturę żywego słowa, służba prawdzie, dobru i pięknu to ideały, które wiążą ten teatr z jego posłannictwem. Danuta Michałowska, aktorka i koleżanka Karola Wojtyły, napisała w jednej z dedykacji, że Hagiograf jest kontynuatorem idei Teatru Rapsodycznego (Bochenek, „Duchowy wymiar sztuki” 15).

Pewnym problemem może być umieszczenie tego teatru wśród grup amatorskich, bowiem jego założycielka i główna odtwórczyni większości ról, Izabela Drobotowicz-Orkisz, nie jest amatorką. Studiowała ona w Państwowej Wyższej Szkole Teatralnej w Krakowie. Wtedy też należała do duszpasterstwa akademickiego Beczka ojców dominikanów. Tam prowadziła swoją grupę i służyła duszpasterstwu artystycznymi zdolnościami. Była to kontynuacja tego, co robiła w swojej rodzimej, gdańskiej parafii - gdzie założyła z przyjaciółmi duszpasterstwo młodzieży i występowała w wieczornicach. Ukończywszy w 1983 roku studia występowała przez wiele lat m.in. w Teatrze Wybrzeże w Gdańsku. Po dwunastu latach, mając dobre recenzje swoich ról, postanowiła odejść z tego teatru, gdyż nie chciała grać w sztukach, z których przesłaniem się nie utożsamiała. Znikając z zawodowej sceny teatralnej, nie zaniechała jednak swej działalności, rozwoju artystycznych pasji i głoszenia nauki Jana Pawła II na scenie. Stara się ciągle odpowiadać na potrzebę nowej kultury, opartej na szacunku dla prawdy, dobra i piękna.

Izabela Drobotowicz-Orkisz pracuje od wielu lat na tekstach papieskich, w związku z tym nieustannie zgłębia nauczanie Jana Pawła II. Każde wcześniejsze spotka- 
nie z Ojcem Świętym było dla niej wielkim przeżyciem, z którego ciągle czerpie inspirację dla swych działań (Bochenek, „Spotkanie” 3).

Hagiograf realizuje przede wszystkim projekty propagujące twórczość i nauczanie Jana Pawła II. Były to spektakle w ramach Uniwersytetu Kultury Polskiej w Rzymie oraz cykl artystyczno-religijnych, comiesięcznych spotkań „Oblicza imion”, które od 2002 roku przybliżają publiczności wielkie postaci Kościoła - świętych, błogosławionych, a także kandydatów do wyniesienia na ołtarze. Teatr ten gra swe spektakle w wielu miastach, miasteczkach i wioskach Polski, ale występował także we Włoszech oraz w Czechach, Szwecji i Kanadzie. Od 2016 roku stanowi sekcję kultury Fundacji Naukowej Instytutu Karola Wojtyły.

W repertuarze Hagiografu są spektakle, które gatunkowo należą do teatru słowa. Scenariusze są budowane na podstawie różnych tekstów, osobistych zapisków, dzienników duszy. Wiele z nich powstało z inspiracji nauczania papieża Polaka. Teatr wystawił kilkukrotnie w formie czytania performatywnego wszystkie dramaty Karola Wojtyły. Na podstawie dramatu Brat naszego Boga powstał Artysta Miłosierdzia, w którym twórcy skupili się na ukazaniu trudnej drogi duchowej, jaką przeszedł Adam Chmielowski, zanim stał się bratem Albertem. Równoważnym wątkiem obok wyboru powołania jest w tym spektaklu dyskurs wartości chrześcijańskich z ideologią marksistowską.

Hagiograf zrealizował również kilka przedstawień zbudowanych na wybranych fragmentach homilii Jana Pawła II skierowanych do Polaków podczas wszystkich pielgrzymek do Ojczyzny (Nie lękajcie się) czy na rozważaniach ostatniej rzymskiej Drogi Krzyżowej Papieża w Koloseum w 2005 roku (Ogród zmartwychwstania). Powstało przedstawienie Portrety, będące zobrazowaniem konstelacji postaci z poezji i dramatów Karola Wojtyły, a także Czeka Cię niebo, w którym autorzy starali się uchwycić zachwyt Papieża nad tajemnicą Bożego Miłosierdzia. Warto zwrócić uwagę, że chociaż działalność tego teatru nie jest widoczna w mediach, to jednak przez wielką liczbę spotkań, spektakli czy wydarzeń parateatralnych - zajmuje istotne miejsce w przestrzeni działań promujących i rozpowszechniających idee zawarte w nauczaniu papieskim.

\section{MUSICALOWA WERSJA ŻYCIA KAROLA WOJTYŁY}

W 2017 roku w krakowskiej Tauron Arenie odbyła się światowa premiera musicalu $\mathrm{Karol}^{15}$, czyli zrealizowanej z wielkim rozmachem opowieści o życiu chłopca

\footnotetext{
${ }^{15}$ Karol, musical o Życiu Jana PawŁa II. Libretto, kierownictwo artystyczne - Michał Kaczmarczyk, muzyka - Filip Siejka, reżyseria - Krzysztof Korwin Piotrowski, premiera 25 II 2017. www. musical-karol.pl. Dostęp 15.03.2020.
} 
z Wadowic, którego Bóg zaprowadził do Watykanu. Miała ona się wpisać w promowanie życia i myśli Jana Pawła II. Poprzez musicalową formę jej twórcy pragnęli dotrzeć do szerokiej, zwłaszcza młodej publiczności. Powstał spektakl przygotowany z największym, jak dotąd, rozmachem scenicznym w Polsce. Jacek Kawalec, który w musicalu grał główną rolę, pragnął ukazać swego bohatera jako osobę, która uczyła innych, by na drugiego człowieka patrzeć jak na bliźniego, a nie jak na wroga.

Michał Kaczmarczyk, kierownik artystyczny musicalu i autor libretta, wskazywał na Papieża jako człowieka bliskiego drugiemu człowiekowi, który będąc poetą, filozofem, sportowcem, zmienił oblicze Watykanu i całego świata. Widz po zakończonym musicalu miał wyjść z przekonaniem, że Jan Paweł II naprawdę był świętym, który odmienił oblicze ziemi. Miał też przypomnieć sobie o otwarciu się na drugiego człowieka i na inne religie oraz o wierze w ludzkie dobro ${ }^{16}$. W spektaklu wykorzystano muzykę nie tyle musicalową, ile popularną, zaś wśród wykonawców znalazły się gwiazdy polskiej estrady: Edyta Geppert, Anna Wyszkoni i bracia Cugowscy. Miało to pewnie przyciągnąć młodzież, która już nie pamięta bezpośrednio postaci Papieża. Niestety, cała forma była na tyle rozbudowana i stworzona z myślą o komercyjnym sukcesie widowiska, że przesłoniła przesłanie. Włączenie zaś do spektaklu oryginalnych piosenek popularnych wykonawców tylko uwydatniło komercyjne założenia przygotowywanego widowiska. Spektakl zagrano tylko jeden raz, a zamiar zorganizowania tournee po największych salach i arenach widowiskowych w Polsce (Łódź, Gdańsk-Sopot, Wrocław, Gliwice, Toruń) tak, by widowisko o Świętym zobaczyli widzowie w całej Polsce i za granicą, nie został zrealizowany.

Warto także zauważyć, że nie jest to pierwsza taka próba przełożenia życia Karola Wojtyły na scenę musicalową. Wcześniej, w 2014 roku było w Polsce zrealizowane włoskie przedstawienie Karol Wojtyła. Historia prawdziwa, które również doczekało się tylko kilku prezentacji (Kraków, Warszawa). Niemniej wydaje się, że proste przełożenie życia i działalności Jana Pawła II na formę musicalową ciągle czeka na oryginalnych twórców, którzy będą chcieli opowiedzieć coś ważnego, a nie tylko stworzyć okazję do skomercjalizowanego sukcesu.

Odkrywanie myśli zawartych w tekstach dramaturgicznych Karola Wojtyły jest bardzo ważnym aspektem poznawania idei przyświecających jego życiu i nauczaniu. Jego dramaty, ale też i inne utwory literackie bardzo często były realizowane na sce-

${ }^{16}$ M. ŁĄCKA, Papież, który odmienit oblicze ziemi - premiera musicalu o Wojtyle, info.wiara.pl/ doc/3717219.Papiez-ktory-odmienil-oblicze-ziemi-premiera-musicalu-o-Wojtyle. Dostęp 20.03.2020. 
nie. Zajmowały się tym teatry zawodowe, zarówno te stacjonarne, jak i teatry radia czy telewizji, ale też całe grono środowisk amatorskich, działających na różnych scenach. W Polsce, po wyborze Jana Pawła II, pojawiły się zespoły teatralne mające na celu promocję myśli papieskiej. Takimi grupami są Droga z Poznania, Hagiograf z Krakowa, czy też działający przez wiele lat w Gliwicach Teatr Karola. Weszły one niejako w przestrzeń opuszczoną przez grupy zawodowe. Oprócz ich działań wiele innych grup teatralnych (Logos, ITP, teatry seminaryjne) co pewien czas wystawiają dramaty Wojtyły na scenie. Wśród wielu lepszych i słabszych spektakli można dostrzec istotną rolę, jaką pełnią te niezawodowe środowiska. Realizując zarówno dramaty Wojtyły, montaże poetyckie oparte na jego twórczości czy spektakle (np. musicale) opisujące życie Jana Pawła II - wszystkie te grupy spełniają wielce użyteczne zadanie w przybliżaniu myśli Papieża-Polaka, zwłaszcza swym rówieśnikom.

\section{BIBLIOGRAFIA}

Babicki, Krzysztof. „Zadania teatru repertuarowego”. Dylematy dramatu i teatru u progu XXI wieku, red. Anna Podstawka, Agnieszka Jarosz, Wydawnictwo KUL, 2011, ss. 341-350.

Bańkowski, Tadeusz. „Popularny teatr religijny dzisiaj”. Dramat i teatr sakralny, red. Irena Sławińska, Redakcja Wydawnictw Katolickiego Uniwersytetu Lubelskiego, 1988, ss. 263-284.

Bochenek, Małgorzata. „Duchowy wymiar sztuki”. Nasz Dziennik, nr 240, 2018, s. 5.

Bochenek, Małgorzata. „Spotkanie, które wycisnęło niezatarte znamię”. Nasz Dziennik, nr 128, 2009, s. 3.

Ciechowicz, Jan. „Światopogląd teatralny Karola Wojtyły”. Dialog, nr 10, 1981, ss. 116-122.

Jakubowski, Henryk Tymon. Amatorski ruch teatralny. Centralny Ośrodek Metodyki Upowszechniania Kultury, 1975.

Kaczmarek, Wojciech. „Formy i przejawy współczesnego teatru religijnego w Polsce (1979-1989)”. Wokót współczesnego dramatu i teatru religijnego w Polsce (1979-1989), red. Irena Sławińska i Wojciech Kaczmarek, Wiedza o Kulturze, 1993, ss. 11-29.

Kołodziejska, Anna. Karol Wojtyła - dramaturg. Twórczość dramatyczna oraz związi Karola Wojtyly $z$ Teatrem Rapsodycznym, Self Publishing, 2015.

Kruszyńska, Anna. „Karol Wojtyła: aktor, poeta, dramaturg”, www.e-teatr.pl/p1/artykuly/265550, druk. html. Dostęp 20.02.2020.

Lach, Mariusz. „Amatorski teatr religijny w latach 1980-2005. Rekonesans”. W kręgu polskiego dramatu i teatru religijnego XX wieku, red. Joanna Michalczuk i Wojciech Kaczmarek, Norbertinum, 2007, ss. 167-178.

Lach, Mariusz. Kilka szkiców na temat amatorskiego teatru religijnego dziś. Norbertinum, 2009.

Machniak, Jan. „Bóg i człowiek w poezjach Karola Wojtyły - Jana Pawła II, cz. V”, www.janmachniak. pl/index.php/moje-wyklady-2/53-bog-i-czowiek-w-poezjach-karola-wojtyy-jana-pawa-ii-cz-v. Dostęp 15.02.2020.

Marczewski, Andrzej Maria. „Teatr Karola Wojtyły”, www.marczewski.pl. Dostęp 20.03.2020.

Olszewska, Maria Jolanta. „Piękno Miłosierdzia. Dramaturgiczne wizerunki Brata Alberta”. Zeszyty Naukowe KUL, nr 2, 2018, ss. 121-143.

Przestrzeń słowa. Twórczość literacka Karola Wojtyły - Jana Pawła II, red. Zofia Zarębianka i Jan Machniak, Wydawnictwo św. Stanisława BM, 2006. 
Sawicki, Stefan. „Uwagi o teatrze studenckim”. Zeszyty Naukowe KUL, nr 2, 1958, ss. 125-135.

Taborski, Bolesław. Karola Wojtyly dramaturgia wnętrza. Szkice. Redakcja Wydawnictw KUL, 1989. Wielechowska, Katarzyna. „Medytacja obecności. „Dramaty wnętrza” Karola Wojtyły”. Acta Universitatis Lodziensis. Folia Litteraria Polonica, nr 10, 2008, ss. 199-217.

Wojtyła, Karol. „O teatrze słowa”. XXV lat Teatru Rapsodycznego w Krakowie 1941-1966, red. Mieczysław Kotlarczyk, Teatr Rapsodyczny, 1966, ss. 126-129.

Wojtyła, Karol. Poezje i dramaty. Wybór i układ Marek Skwarnicki i Jerzy Turowicz, Znak, 1979.

\section{AMATORSKIE REALIZACJE TEATRALNE DRAMATÓW KAROLA WOJTYŁY}

Streszczenie

W promowaniu idei zawartych w dramatach Karola Wojtyły istotną rolę, obok scen zawodowych, pełnią środowiska amatorskie. Brat naszego Boga i Przed sklepem jubilera, a także różne montaże poetyckie oparte na poezji Wojtyły na stałe zagościły do repertuarów mniejszych grup teatralnych. Niektóre z nich, jak „Droga” z Poznania, „Teatr Karola” z Gliwic czy „Hagiograf” z Krakowa swoje istnienie i działania podporządkowują celowi, jakim jest promocja myśli i twórczości papieża Polaka. Różnorodność form, od spektakli rapsodycznych, przez montaże słowno-muzyczne, aż po formy bardzo popularne, jak na przykład musicale, sprawia, że idee, które zostawił w swych pismach Jan Paweł II, ciągle znajdują nowych odbiorców.

Słowa kluczowe: dramat sakralny; teatr amatorski; dramaturgia Karola Wojtyły; teatr studencki; teatr religijny

\section{THE AMATEUR THEATRE PERFORMANCES OF KAROL WOJTYŁA'S PLAYS}

Sum mary

Amateur theatre circles play an important role in promoting the ideas contained in Karol Wojtyła's dramas. Our God's Brother and In front of the Jeweller's Shop, as well as various poetic works based on Wojtyła's poetry, have permanently entered the repertoire of smaller theatre groups. Some of these, such as "Droga" from Poznań, "Teatr Karola" from Gliwice or "Hagiograf" from Cracow, subordinate their existence and actions to the goal of promoting the thoughts and works of the Polish Ppope. The variety of forms, from rhapsodic performances to musicals, means that the ideas that John Paul II left in his writings can still find new recipients today.

\section{Translated by Julia Laskowska}

Keywords: sacred drama; amateur theatre; dramaturgy of Karol Wojtyła; student theatre; religious theatre 